\title{
Disruption of Botrytis cinerea Pectin Methylesterase Gene Bcpme1 Reduces Virulence on Several Host Plants
}

\author{
Odile Valette-Collet, ${ }^{1}$ Agnès Cimerman, ${ }^{1}$ Philippe Reignault, ${ }^{2}$ Caroline Levis, ${ }^{3}$ and Martine Boccara ${ }^{1}$ \\ ${ }^{1}$ Pathologie Végétale UMR217, Institut National Agronomique 75231 Paris, France; ${ }^{2}$ Laboratoire de Biochimie et \\ Pathologie végétales, Université Pierre et Marie Curie, 4 place Jussieu 75252 Paris, France; ${ }^{3}$ Phytopathologie et \\ Méthodologie de la Détection, INRA 78026 Versailles, France
}

Submitted 12 September 2002. Accepted 16 December 2002.

\begin{abstract}
The pectinolytic enzyme pectin methylesterase (PME) hydrolyses pectin in methanol and polygalacturonic acid. In the expressed sequence tag library of Botrytis cinerea T4, we identified a 1,041 bp Bcpme1 cDNA potentially encoding a 346-amino acid protein of $37 \mathrm{kDa}$ showing 46.8\% identity with Aspergillus sp. PMEs. Bcpme1 is a single copy gene and is similarly expressed in glucose and pectin containing media. To evaluate the role of Bcpme1 in Botrytis cinerea virulence, a mutant in Bcpme1 was generated by gene disruption. The Bcpme1 mutant showed similar growth on rich medium but reduced growth on pectin medium. Two isozymes of pI 7.4 and 7.1 were detected in pectin liquid-culture supernatants of wild-type strain Bd90 analyzed by isoelectric focusing-polyacrylamide gel electrophoresis, while those of Bcpme1 mutant possessed only the pI 7.1 isozyme. BCPME1, the pI 7.4 isozyme, is the major PME activity, as PME activity is $75 \%$ reduced in Bcpme1 mutant. Moreover, the Bcpme1 mutant was less virulent on apple fruits, grapevine, and Arabidopsis thaliana leaves. Those phenotypes were complemented by reintroducing a Bcpme1 copy in the Bcpme1 mutant. These results showed that $B$. cinerea possessed more than one PME-encoding gene and that BCPME1 is an important determinant of $B$. cinerea virulence.
\end{abstract}

While invading their hosts, many phytopathogenic bacteria and fungi synthesize extracellular enzymes that degrade pectin, the major component and the most complex polysaccharide in the plant cell wall, particularly abundant in the middle lamella. Pectin consists of "hairy" and "smooth" regions. The hairy region, known as rhamnogalacturonan, is characterized by stretches of $\alpha$-1-2-L-rhamnose and $\alpha$-1-4-D-galacturonic acid dimers. The smooth region, or homogalacturonan part, consists of a backbone of $\alpha-1-4-$ linked D-galacturonic acid residues, which are partly methylated and can be acetylated. Pathogens produce an arsenal of suitable smooth pectin depolymerizing enzymes: pectin methylesterases (PME, E.C. 1.1.11), which deesterifie pectin into methanol and polygalacturonic acid (PGA), allowing subsequent action of polygalacturonases (PG, E.C. 3.2.1.15), which cleave glycosidic bonds by hydrolysis

Current address of P. Reignault: Mycologie/Phytopathologie/Environnement, Université du Littoral Côte d'Opale, B.P.699 62228 Calais, France

Corresponding author: M. Boccara: boccara@ccr.jussieu.fr

This article is in the public domain and not copyrightable. It may be freely reprinted with customary crediting of the source. The American Phytopathological Society, 2003. and pectate lyases (PL, E.C. 4.2.2.2), which break PGA into oligogalacturonides by $\beta$-elimination. Pectin lyases (PNL, E.C. 4.2.2.10) also depolymerize native pectin by breaking bonds between methylated galacturonide residues via $\beta$-elimination.

The role of these different activities during bacterial or fungal infections has been addressed for several years. Approaches used in initial studies, such as analysis of enzyme activities in culture supernatant or decayed tissues, provided only correlations between the amount of pectinolytic enzymes produced and the extent of symptom development, especially in diseases characterized by soft-rotting symptoms (Alghisi and Favaron 1995). But in the last decade, gene disruption has allowed researchers to determine which attributes could be considered as factors of virulence. Concerning pectinolytic enzymes in filamentous fungi, the majority of studies focused on PGs. Their clear involvement in fungal pathogenicity is still debated. Indeed, several targeted mutants showed no reduction in pathogenicity (Bowen et al. 1995; Gao et al. 1996; Scott-Craig et al. 1998), while others demonstrated that the studied pectinolytic enzyme was essential for fungal attack (Isshiki et al. 2001; Oeser et al. 2002; Rogers et al. 2000; Shieh et al. 1997; Ten Have et al. 2002; Yakoby et al. 2000).

B. cinerea Pers.:F. (teleomorph: Botryotinia fuckeliana (de Bary) Whetzel), a broad-host-range necrotrophic pathogen, is responsible for many economic losses on fruits, vegetables, and flowers, causing soft-rotting symptoms (Coley-Smith et al. 1980). B. cinerea secretes numerous pectinolytic enzymes, especially PGs and PMEs. Ten Have and associates (1998) showed by partial gene replacement that mutants in Bcpg1, a gene coding for an endopolygalacturonase, were still pathogenic but that Bcpgl was required for full virulence of $B$. cinerea, i.e., for expanding lesions beyond the inoculation point. As endo-PGs are encoded by a multigenic family in $B$. cinerea (Wubben et al. 1999), the abolition of one gene of endo-PG can be compensated by the others.

Hardly anything is known about the contribution of PMEs in filamentous fungi pathogenicity, although evidence for PME activities has been found in many phytopathogenic fungi (Rexova-Benkova and Markovic 1976), including biotrophic fungi such as Uromyces viciae-fabae (Frittang et al. 1992). Nevertheless, PME activity may be of major importance for complete degradation of pectin by PGs and PLs, since these enzymes are not able to cleave highly methyl-esterified pectin. Evidence was provided by the disruption of the PMEA encoding gene in the soft-rotting bacterium Erwinia chrysanthemi, resulting in a strong reduction in virulence on the African violet Saintpaulia ionantha (Beaulieu et al. 1993; Boccara and Châtain 1989).

For all the reasons above, we chose to focus our work on the role of $B$. cinerea PME activity in virulence. In previous studies, 
Reignault and associates (1994) purified PME activity consisting in a single protein band of $42 \mathrm{kDa}$ that corresponded to two distinct PME isozymes of $\mathrm{pI} 7.1$ and 7.4, suggesting that, unlike PGs, PMEs were encoded by a small number of genes. In this paper, we report the isolation and the cloning of a $B$. cinerea pectin methylesterase encoding gene, Bcpmel. We studied the expression of Bcpmel in different conditions. We then constructed a Bcpme1 disrupted mutant to determine how the loss of this activity affected the ability of $B$. cinerea to use pectin as sole carbon source and to attack and invade several host plants.

\section{RESULTS}

\section{Characterization of Bcpme1 coding sequence.}

By running a Blastn between the 6,800 expressed sequence tag (EST) library of B. cinerea T4 (at the Genoscope website) and the pmeA gene from Aspergillus niger (accession number X54145), we identified an EST clone (AL114776.1) whose deduced protein sequence showed $48.6 \%$ identity with the deduced protein sequence of pmeA from A. niger. The corresponding cDNA clone was fully sequenced and appeared to contain an open reading frame of $1,041 \mathrm{bp}$, which we designated Bcpme1 (accession number AF309701).

The Bcpmel gene encodes a putative protein of 346 amino acids with calculated molecular weight and $\mathrm{pI}$ of $37.2 \mathrm{kDa}$ and
7.08, respectively. The analysis of the BCPME1 sequence with PROSITE showed the characteristic signature VVGAIDFIFG (Markovic and Jörnal 1992) of PME possibly involved in determining the active site of the enzyme. BCPME1 also contains four putative glycosylation sites $\left({ }^{89} \mathrm{Asn}-\mathrm{Leu}-\mathrm{Thr},{ }^{238} \mathrm{Asn}-\right.$ Asn-Ser, ${ }^{246}$ Asn-Ser-Ser, and ${ }^{308}$ Asn-Ser-Ser), which could explain the difference between the calculated molecular weight and the $42-\mathrm{kDa}$ protein observed on sodium dodecyl sulfatepolyacrylamide gel electrophoresis (SDS-PAGE) analysis, and it is in agreement with the $30 \%$ carbohydrate content found in a previous study (Reignault et al. 1994). $\mathrm{NH}_{2}$-terminal sequencing of the purified PME showed that the mature protein began at amino acid 27 (Fig. 1). So BCPME1 may contain a 20-amino-acid signal peptide that is cleaved off during passage of the endoplasmic reticulum membrane and a 6-amino-acid propeptide (Van den Ackerveken et al. 1992) that is cleaved at the monobasic cleavage site (between ${ }^{26} \mathrm{Arg}$ and ${ }^{27} \mathrm{Ala}$ ) during protein maturation and secretion. Three internal microsequences determined from the purified PME were identical to portions of the predicted sequence from the Bcpme1 cDNA. BCPME1 showed 47.3, 46.6, 46.6, and 50.6\% amino acid identity with A. aculeatus, A. niger, A. oryzae, and Cochliobolus carbonum PME sequences, respectively. Comparisons of primary structures of previously known PMEs revealed six highly conserved segments (Laurent et al. 1993; Spök et al. 1991). Those six regions were also found in BCPME1 (Fig. 1).

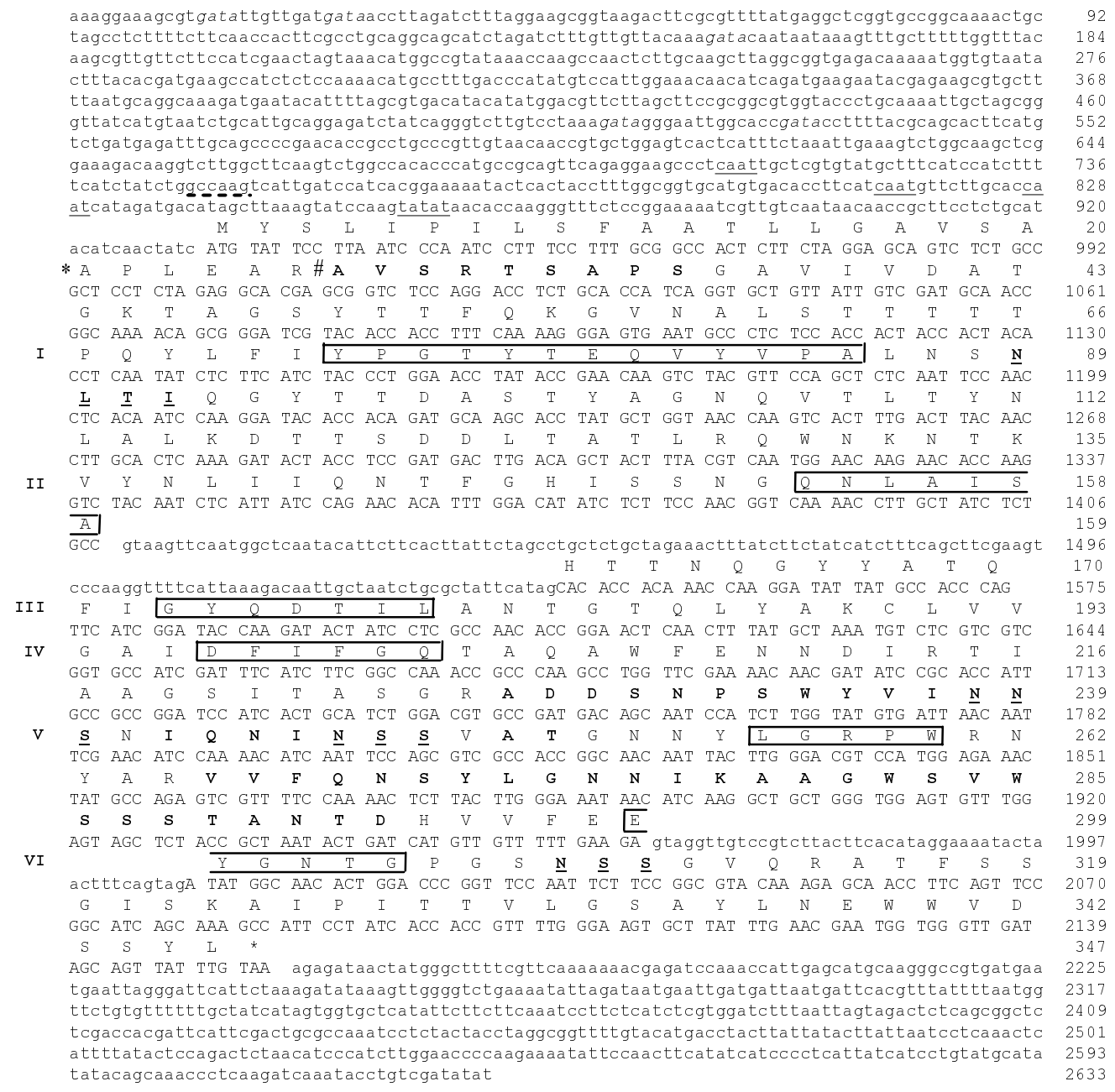

Fig. 1. Nucleotide and derived amino acid sequences of the Bcpmel gene from Botrytis cinerea. The amino acids determined chemically are in bold. Potential N-glycosylation sites are underlined and in bold. Conserved regions are boxed. Introns are shown by lower-case letters. In the promoter region, putative TATA and CAAT boxes are underlined and GATA motifs are in italics.* indicates the putative cleavage site of signal peptide, and \# indicates the putative cleavage site of pro-peptide. The GCCARG motif is underlined by dashes. 
The Bcpme1 gene is expressed

in glucose and pectin-containing media.

The nucleotidic sequence comparison between polymerase chain reaction (PCR) amplifications on Bd90 genomic DNA and cDNA Bcpmel sequence showed the existence of two introns of 133 and $48 \mathrm{bp}$, respectively (Fig. 1). Gene walking was performed to clone upstream and downstream genomic regions of Bcpmel coding sequence. The 5' untranslated region revealed a putative TATA box located at $-72 \mathrm{nt}$ and three putative CAAT boxes between -227 and -104 nt (Fig. 1).

The expression of Bcpmel gene was studied by semiquantitative reverse transcription (RT)-PCR experiments (discussed below) with RNA extracted from strain Bd90 grown for $48 \mathrm{~h}$ in glucose or pectin-containing media. Signal intensities of amplified fragments were very similar (in glucose, $92,764 \pm 5,552$ arbitrary unites (AU) and in pectin, 95,252 $\pm 5,463 \mathrm{AU}$ ).

The Bcpmel upstream sequence also contained several GATA motifs, which constituted the recognition sequence of major nitrogen regulatory proteins AREA in A. nidulans (Kudla et al. 1990) and NIT2 in Neurospora crassa (Fu and Mazluf 1990). We tested whether Bcpmel could be regulated by nitrogen level in the medium. No difference in signal intensity of amplified fragments was observed between media containing $0.3 \mathrm{mM}$ and $30 \mathrm{mM} \mathrm{NO}_{3}$ (data not shown).

\section{The Bcpme1 gene is a single copy gene.}

Southern blot analysis of genomic DNA, isolated from several strains of B. cinerea and digested with BamHI, EcoRI, or HindIII and hybridized with Bcpmel cDNA as probe, showed only one hybridizing fragment (Fig. 2). The two hybridized fragments observed with BamHI digestion could be explained by the presence of a BamHI restriction site in the Bcpmel sequence. These results suggested that Bcpmel was present as a single copy gene in the haploid genome of $B$. cinerea and that a slight polymorphism existed between different strains at this locus.

\section{Construction of a Bcpme1 interrupted mutant.}

A Bcpme1 mutant was obtained by a transformation-mediated gene disruption in the wild-type strain Bd90. An 831-bp fragment was PCR-amplified with homologous primers (WOD and AFBR) on Bd90 genomic DNA and was cloned in plasmid pAN7-1. The derived plasmid pibcpmel contained the $h p h$ gene conferring resistance to hygromycin and was used to transform strain Bd90. From one transformation experiment, 30 independent transformants were obtained. Seventeen hygromycinresistant colonies were analyzed by PCR, using AVWOD and FTtrpC primers to select transformants containing pibcpmel inserted at the Bcpmel locus (Fig. 3A). No PCR product was amplified with genomic DNA from strain Bd90, while a 1-kb

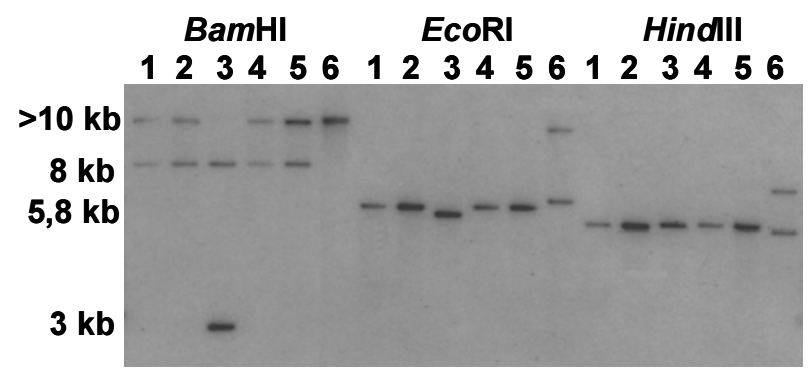

Fig. 2. Southern analysis of genomic DNA from several strains of Botrytis cinerea and one strain of $B$. allii digested by $B a m \mathrm{H} 1, E c o \mathrm{RI}$, and HindIII and hybridized with Bcpme1 cDNA as probe. Lane 1, Bd90; lane 2, B05.10; lane 3, Br94; lane 4, SAR2108; lane 5, SAR10993; and lane 6, B. allii. amplification product was expected with transformant genomic DNA where insertion of pibcpmel at the Bcpmel locus had occurred. Of 17 hygromycin-resistant transformants, 12 transformants for which no amplification was obtained exhibited ectopic insertions of pibcpmel, and four for which the 1-kb product was amplified with AVWOD and FTtrpC primers were disrupted at the Bcpmel locus. In one transformant, a fragment of more than $1 \mathrm{~kb}$ was amplified, suggesting rearranged insertion at the Bcpmel locus (data not shown). Southern analysis of the four disrupted transformants was performed, and mutant B21 was found to be the only homocaryotic transformant with multiple tandem insertions of pibcpmel at the Bcpmel locus (Fig 3B). The three other disrupted transformants after four rounds of monospore isolation still possessed the wild-type copy of the Bcpmel gene. Mutant B21 was chosen for further characterization and pathogenicity studies.

\section{Bcpme1 encodes the major PME activity of B. cinerea.}

PME activity was measured in supernatants from Czapeckpectin liquid medium. Mutant B21 (PME-specific activity, 0.32 $\pm 0.12 \mathrm{U}$ per $100 \mathrm{mg}$ mycelial dry weight) showed about $75 \%$ PME activity reduction compared with PME activity of wildtype strain Bd90. The same supernatants were subjected to a thin-layer polyacrylamide gel isoelectric focusing (IEF) and were analyzed for PME activities. The two expected activities corresponding to the isozymes of pI 7.1 and 7.4, respectively, were observed in the culture filtrate of wild-type strain $\mathrm{Bd} 90$. The supernatant of mutant B21 neither contained the pI 7.4 isozyme nor the $\mathrm{pI} 6.5$ isozyme, indicating that the latter is also encoded by the Bcpmel gene (Fig. 4A). The activity of pI 6.5 resulted probably from partial modification of BCPME1.

Extracts from uninfected apple fruits showed a strong basic isozyme of pI 8.4 and a diffuse and faint band corresponding to an isozyme of $\mathrm{pI}$ 6.8. IEF-polyacrylamide gel electrophoresis (IEF-PAGE) with protein extracts from macerated regions of apple fruits infected with either wild-type strain Bd90 or mutant B21 showed that PME profile was as complex as already shown by Reignault and associates (2000). However, we noticed the absence of the isozyme corresponding to BCPME1 in extracts from apples infected by mutant B21. The intense band of pI 7.4 observed with extracts from apples infected with strain Bd90 demonstrated that BCPME1 was strongly secreted in planta (Fig. 4B).

\section{The Bcpme1 mutant $\mathrm{B} 21$ is reduced in its ability} to grow on pectin and in its virulence on several host plants.

The radial growth on solid medium was measured on medium containing different carbon sources. On rich media, such as potato dextrose agar (PDA) and nutrient yeast (NY), and on Czapeck-PGA 1\%, no difference was found between the mutant B21 and wild-type strain Bd90 (data not shown). Furthermore, mutant B21 sporulated and produced sclerotia equally as well as Bd90 (data not shown). However, on medium containing $66 \%$ esterified pectin as the sole carbon source, mutant B21 growth was reduced in about $20 \%$ at $96 \mathrm{~h}$ postinoculation (Fig. 5). The similar growth observed for mutant B21 and wildtype strain Bd90 after $24 \mathrm{~h}$ could be explained by the utilization by the fungus of carbon sources contained in the agar plug used as inoculum.

Mutant B21 pathogenicity was checked on three different host plants, Arabidopsis thaliana ecotype Ws leaves, Vitis vinifera cv. Chardonnay leaves, and Malus domestica cv. Granny Smith apple fruits. On apple fruits, mutant B21 produced brown, rotten lesions around the inoculation sites, as did wild-type strain Bd90. There was no significant difference in necrosis diameter between mutant B21 and wild-type strain Bd90 (data not shown). However, while measuring fresh 
weight of macerated tissues four days after inoculation, apples inoculated with mutant B21 showed a $30 \%$ reduction in tissue maceration compared with those inoculated with the wild-type strain Bd90 (Fig. 6A). Grapevine leaves inoculated with mutant B21 presented reduced lesions compared with those observed on leaves infected by strain Bd90. Globally, leaves infected by mutant B21 showed about $50 \%$ symptom reduction (Fig. 6B). The virulence of mutant B21 was even more reduced on Arabidopsis thaliana leaves. For most inoculated leaves, mutant B21 was not able to cause lesions and sporulated abundantly on the agar plug used as inoculum (Fig. 6C and Table 1 ). When infection was successful, lesion sizes were $77 \%$ reduced compared with lesions produced by wild-type strain Bd90 (Table 1). A Student's $t$ test made for each experiment on the three tested host plants showed that lesions caused by the mutant B21 were significantly smaller than those caused by the wild-type strain Bd90.

\section{Complementation of the mutant B21.}

The mutant B21 was complemented using a plasmid containing the Bcpmel gene with part of its promoter (929 bp) and of its terminator $(458 \mathrm{bp})$ and the bar gene conferring resistance to the herbicide Basta. Five complemented clones were analyzed. When grown on Czapeck-pectin medium, they all showed PME isozyme profiles identical to the profile of wildtype strain Bd90, including PME activity of pI 7.4 (Fig. 4A). The complemented clones possessed approximately the same total PME activity $(1.26 \pm 0.07 \mathrm{U}$ per $100 \mathrm{mg}$ mycelial dry weight) as wild-type strain Bd90. In addition, the complemented clones were as pathogenic as wild-type strain $\mathrm{Bd} 90$ on A. thaliana (Table 1) and grapevine leaves (Table 2).

\section{DISCUSSION}

In this paper, we described the cloning of the Bcpmel gene encoding for a pectin methylesterase from Botrytis cinerea and the construction of a mutant disrupted in the Bcpmel gene. We showed that Bcpmel encodes the major PME activity secreted by $B$. cinerea, that a mutation in this gene has a profound effect on fungal development in pectin-containing medium and in planta, and that complementation of the Bcpmel mutant restores wild type phenotype.

To our knowledge, the Bcpmel gene is the first pme gene cloned from a phytopathogenic fungus causing soft-rotting symptoms. As expected, BCPME1-deduced protein sequence is closer to fungal PMEs (48\% mean identity) than to bacterial or plant PMEs (21\%). Molecular mass of BCPME1 is in the same range as other known fungal PMEs, such as those of $A$. aculeatus PME I (36.2 kDa) (Christgau et al. 1996), A. niger PME (43 kDa) (Khanh et al. 1991), and A. oryzae PMEA (38.5 $\mathrm{kDa})$ (Kitamoto et al. 1999). Southern analysis shows that the Bcpmel gene occurs as a single copy gene in Bd90 as well as in all analyzed strains. Furthermore, the positions of the two introns are conserved in two other strains, T4 and K1 (data not shown).

It has been shown previously that PME isozymes were detected whatever the carbon source, glucose, pectin, or polygalacturonic acid (Reignault et al. 1994), suggesting that B. cinerea PME-encoding genes were not submitted to catabolite repression. Consistent with those observations, no CREA binding site (Kulmburg et al. 1993) is detected in Bcpmel promoter and Bcpmel is expressed in glucose-containing medium to the same extent as in pectin-containing medium. Putative GATA binding sequences of nitrogen regulatory proteins are present in the Bcpmel promoter region. The EST library from which Bcpmel was isolated was constructed with mRNA from $B$. cinerea grown in nitrogen starvation conditions. However, the expression of Bcpmel is not stimulated in glucose medium, in which nitrogen is limiting, suggesting that Bcpmel cloning from the EST library is more certainly due to its strong expression in glucose medium. The Bcpmel promoter contains the sequence 5'GCCARG3', a putative site of recognition for PacC transcription factor. $\mathrm{PacC}$ is known to regulate gene expression according to the ambient $\mathrm{pH}$ (Tilburn et al. 1995). Variations in Bcpmel expression when strain $\mathrm{Bd} 90$ is grown at different $\mathrm{pH}$ levels should confirm the validity of this box in Bcpmel promoter.

We constructed a mutant lacking BCPME1 activity by transformation-mediated gene disruption. The disruption of the Bcpmel gene leads to a nonfunctional protein, as the PME of pI 7.4 is not detected by IEF-PAGE analysis, neither in culture supernatants of the mutant B21 nor in apple fruit tissues infected by the mutant B21. Thus, the $\mathrm{C}$ terminal portion of the Bcpmel gene (86 amino acid residues) appears to be essential for BCPME1 activity. This portion of the protein contains one conserved box that could be either part of the catalytic site or could be necessary for the correct folding of the protein BCPME1. So far, the protein structures of only two PMEs

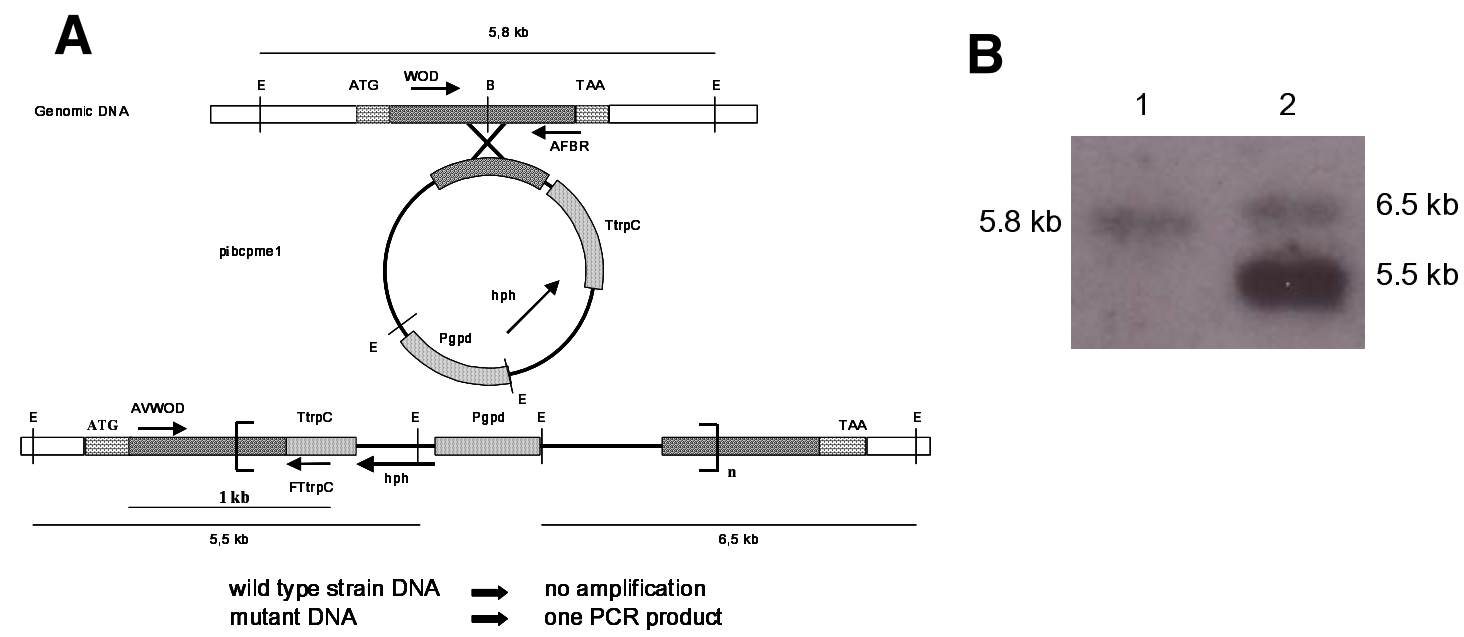

Fig. 3. A, Schematic representation of plasmid pibcpme1 used to transform strain Bd90 of Botrytis cinerea and primer positions for transformant screening by polymerase chain reaction. Restriction enzyme sites: B (BamHI), E (EcoRI). B, Southern blot analysis of genomic DNA digested by EcoRI from wildtype strain Bd90 (lane 1), and the mutant B21 (lane 2) probed with Bcpme1 complete cDNA. The intensity of the band at $5.5 \mathrm{~kb}$ suggests tandem insertions of pibcpme1 at the Bcpme1 locus. 
have been published, from Erwinia chrysanthemi (Jenkins et al. 2001) and from Daucus carota (Johansson et al. 2002). PEMA from E. chrysanthemi and Daucus carota PME have a right-handed parallel $\beta$-helix, as seen in all bacterial and fungal pectic enzymes. It should be interesting to address whether the BCPME1 enzyme adopts the same folding, since no fungal PME has been crystallized, and since the two known structures are from PMEs having highly basic pI (PEMA, 9.6 and Daucus carota PME, 9.8), whereas BCPME1 has a neutral pI (7.4).

PME activity is found to be $75 \%$ reduced in the mutant B 21 . This reduction could be correlated to the reduced growth of mutant B21 in a pectin medium. Indeed, reduced PME activity may result in less substrate for the PG activities and difficulty for mutant B21 to use pectin as sole carbon source. Mutant B21 growth is not reduced on medium containing PGA as the sole carbon source, suggesting that B21 is not affected in PG production. Moreover, IEF-PAGE analysis of supernatants from culture on pectin as the sole carbon source and with infected apple fruit tissues showed identical PG profiles for strains Bd90 and B21 (data not shown).

Since $B$. cinerea causes maceration on a wide range of plants, and since physiological properties of cell wall pectin polymers are controlled by the degree and distribution of methylation, it was legitimate to hypothesize that $B$. cinerea PME activity can be an important determinant of its pathogenicity. Indeed, the potential role of PME in $B$. cinerea pathogenicity has also been recently suggested by Kapat and associates (1998), who showed that $T$. harzarnium isolate T39, a biocontrol agent of $B$. cinerea, may act directly on the fungus by reducing the level of hydrolytic enzymes, including PME, on bean leaves. We demonstrate here that BCPME1 is an essential determinant of $B$. cinerea virulence. Differences in virulence reduction of mutant B21 according to the tested host plant might be due to the diverse degrees of methylation of the pectic compounds of the three tested hosts (Voragen et al. 1986). Recently, the sequencing of the Arabidopsis genome allowed the identification of 67 PME-related genes (The Arabidopsis Genome Initiative 2000). These numerous genes may be involved in regulation of the pectin methylation level in different tissues during A. thaliana growth development. The strong decrease observed for virulence of the mutant B21 on A. thaliana leaves could be correlated with a high methylation level of corresponding pectins.
Finally, although the progression of mutant B21 in vine leaf is slowed down, immunocytological studies with JIM7 antibody (Knox et al. 1990), which recognizes highly methylated pectin, shows that mutant B21 is still able to degrade pectin (data not shown). This suggests that other activities can contribute to pectin degradation. On one hand, it has been shown that $B$. cinerea produces pectin lyase, which is able to depolymerize methylated pectin (Chilosi and Milagro 1997). On the other hand, disruption of the Bcpmel gene revealed the existence of other PME activity. Cloning of other pme genes and construction of mutants should confirm the importance of PME activity in $B$. cinerea virulence.

\section{MATERIALS AND METHODS}

\section{Fungal strains and growth conditions.}

The wild-type reference strain of $B$. cinerea was Bd90 isolated from grapevine. Other $B$. cinerea strains used were SAR2108, SAR10993 isolated from grapevine (Faretra et al. 1988), Br94 (isolated from an apple fruit), B05.10 (haploid laboratory strain) (Büttner et al. 1994), and B. allii (from Allium sp.). They were grown on PDA or NY (malt extract, $20 \mathrm{~g}$ per l; agar, $20 \mathrm{~g}$ per 1 ; and yeast extract, $2 \mathrm{~g}$ per 1) at $23^{\circ} \mathrm{C}$. Czapeck synthetic medium contains $\mathrm{NaNO}_{3}, 30 \mathrm{mM} ; \mathrm{KCl}, 6.7$ $\mathrm{mM} ; \mathrm{MgSO}_{4} ; 7 \mathrm{H}_{2} \mathrm{O}, 0.2 \mathrm{mM} ; \mathrm{K}_{2} \mathrm{HPO}_{4}, 5.7 \mathrm{mM} ; \mathrm{FeSO}_{4} ; 7$ $\mathrm{H}_{2} \mathrm{O}, 36 \mu \mathrm{M}$; and NaMo, $84 \mu \mathrm{M}$ supplemented with either $3 \%$ glucose, PGA (Sigma P3889), or 1\% pectin (Sigma P9165) and adjusted to $\mathrm{pH}$ 6. For culture in solid medium, $1.5 \%$ agar was added. For liquid cultures, conidia $\left(5 \times 10^{7}\right.$ spores $)$ were inoculated into a $250 \mathrm{ml}$ Erlenmeyer flask containing $50 \mathrm{ml}$ of medium.

\section{Genomic Southern analysis and sequencing of Bcpme1.}

Genomic DNA from B. cinerea strains was extracted after $48 \mathrm{~h}$ culture in liquid medium, as described by Sambrook and associates (1989). DNA was digested with BamHI, EcoRI, and HindIII and was size-separated on $0.8 \%$ agarose Tris-borateEDTA $1 \times$ gel. After electrophoresis, DNA was blotted to Hybond $\mathrm{N}^{+}$membranes (Amersham, Saclay, France) by transfer capillarity and hybridized in Church buffer $\left(\mathrm{NaH}_{2} \mathrm{PO}_{4} ; \mathrm{H}_{2} \mathrm{O}\right.$, 27.6 g per 1; $\mathrm{Na}_{2} \mathrm{HPO}_{4}, 42.6$ g per l; SDS, 70 g per 1; EDTA 0.5 $\mathrm{M}, \mathrm{pH} 8,2 \mathrm{ml}$ per 1 ; and bovine serum albumin [BSA], $10 \mathrm{~g}$

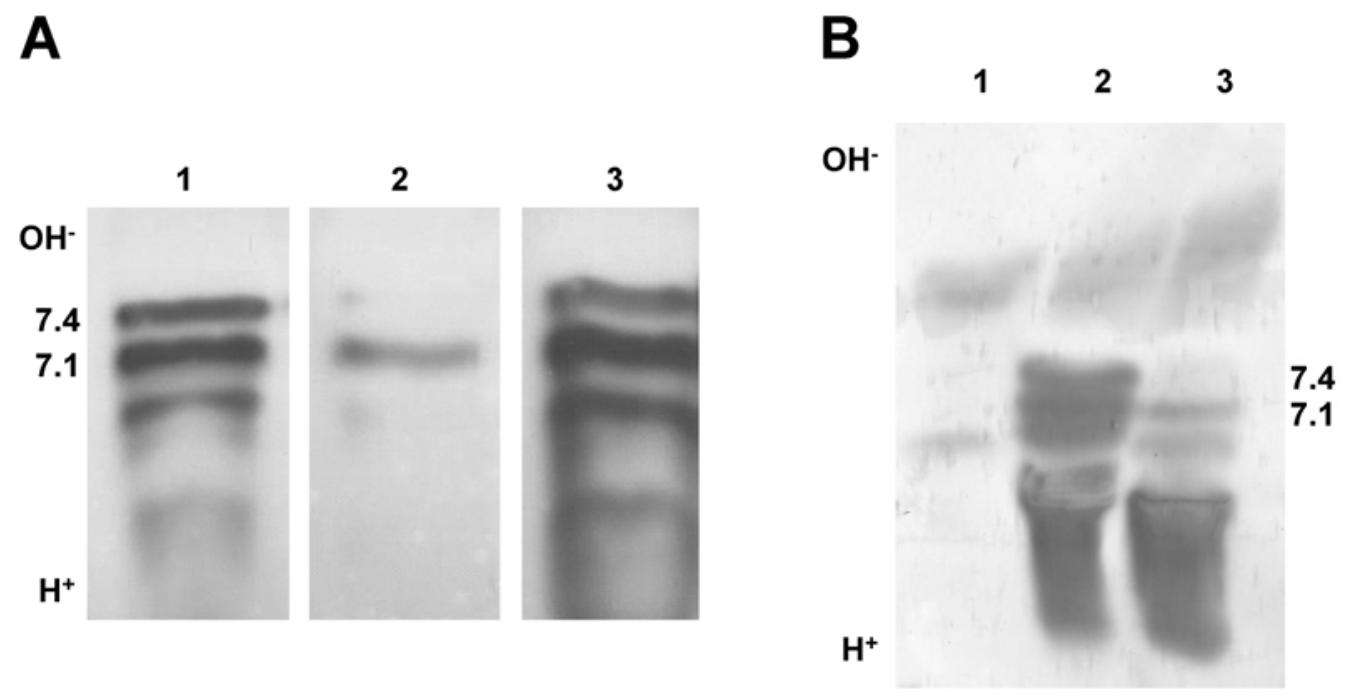

Fig. 4. Revelation of pectin methylesterase activity after isoelectric focusing-polyacrylamide gel electrophoresis (pH range 3 to 10 ). A, Concentrated filtrates from 3-day-old liquid culture on 1\% Czapeck-pectin, strain Bd90 (1), mutant B21 (2), and complemented B21 (3). Amount of protein loaded: (1) $9.6 \mu \mathrm{g}$, (2) $9.5 \mu \mathrm{g}$, (3) $19.2 \mu \mathrm{g}$. B, Proteins extracted from healthy apple fruit (1), apple fruit infected by wild-type strain Bd90 (2), and by mutant B21 (3). Amount of sample loaded on each lane corresponds to $200 \mathrm{mg}$ (fresh weight) of healthy or rotten apple tissues. 
per 1) at $65^{\circ} \mathrm{C}$ overnight. Full-length cDNA was used as a probe and labeled with $[\alpha-32$ P] dATP using a random primer DNA labeling system from Boerhinger (Roche Diagnostics, Meylan, France). Blots were washed twice in $2 \times$ SSC $(1 \times$ SSC is $0.15 \mathrm{M} \mathrm{NaCl}$ plus $0.015 \mathrm{M}$ sodium citrate) and $1 \%$ SDS for half an hour and once in $0.2 \times \mathrm{SSC}$ and $1 \% \mathrm{SDS}$ at $65^{\circ} \mathrm{C}$ and exposed to Kodak X-OMAT film for $48 \mathrm{~h}$.

Gene walking to clone upstream and downstream regions of Bcpmel was performed using the Universal Genome Walker kit (Clontech Labs, Inc., Palo Alto, CA, U.S.A.) following the conditions recommended by the supplier. Primers used were bcpme1pr1 (5' GCGGCAGAGACTGCTCCTAGAAGAGTGG $3^{\prime}$ ) and bcpme1tr1 (5' GGCATCAGCAAAGCCATTCCTATCACC $3^{\prime}$ ) for the $5^{\prime}$ and $3^{\prime}$ noncoding regions, respectively. DNA sequencing was performed by ESGS (European Sequence Gene Service, Groupe Cybergene, Evry, France).

\section{Micro-sequencing of the BCPME1 protein.}

Purified PME protein from B. cinerea $\mathrm{Bd} 90$ was subjected to SDS-PAGE (Reignault et al. 1994). Protein bands were stained with Coomassie brilliant blue and cut out. Then trypsin digestion was performed as follows: $200 \mu \mathrm{l}$ Tris $\mathrm{HCl} 0.1 \mathrm{M}$, pH 8.6, and $0.01 \%$ Tween buffer supplemented with $0.5 \mu \mathrm{g}$ of trypsin during $18 \mathrm{~h}$ at $30^{\circ} \mathrm{C}$. Peptides were separated with high-pressure liquid chromatography on a DEAE-C18 column using an acetonitrile and triflouroacetic acid $0.1 \%$ gradient (0 to $45 \%$ ). $\mathrm{N}$-terminus and internal amino acid microsequences were obtained by Edman degradation with Sequencer Applied Biosystem 494 (Institut Pasteur, Paris).

\section{RNA extraction and RT-PCR analysis.}

RNAs were extracted from frozen mycelium ground in liquid nitrogen, using the RNeasy plant MiniKit (Qiagen, Courtaboeuf, France). RT-PCR reactions were performed with a dilution series from 2 to $50 \mathrm{ng}$ of total RNA, using the onestep RT-PCR kit (Qiagen) and following the manufacturer's instructions. Specific primers were designed (5'TCGATGCAACCGGCAAAACAG3' and 5'GCGGCAATGGTGCGGATATCG3') to span an intron, as contaminating DNA would result in a larger size fragment. Steps of RT-PCR were: RT, $50^{\circ} \mathrm{C} 30 \mathrm{~min} ; \mathrm{PCR}, 15 \mathrm{~min}$ at $95^{\circ} \mathrm{C} ; 25$ cycles of $1 \mathrm{~min}$ at $94^{\circ} \mathrm{C}, 1 \mathrm{~min}$ at $65^{\circ} \mathrm{C}$, and $1 \mathrm{~min}$ at $72^{\circ} \mathrm{C}$; followed by $10 \mathrm{~min}$ at $72^{\circ} \mathrm{C}$. Amplification products were loaded on a $1.2 \%$ agarose gel and were quantified by densitometric analysis using the BIOPROFIL program (Vilber Lourmat, Marne la Vallée,

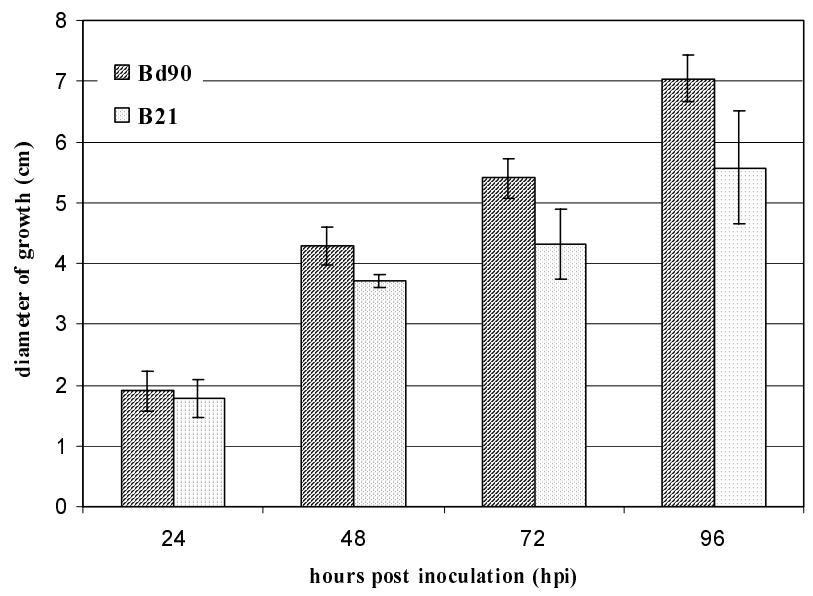

Fig. 5. Radial mycelium growth on $66 \%$ esterified pectin-containing medium at $24,48,72$, and $96 \mathrm{~h}$ postinoculation of Bd90 wild-type strain and the mutant B21 strain. Bars indicate standard deviation of mean of three experiments.
France). Results were expressed in AU representing signal intensity. Proportionality between the fluorescence intensities and the amount of input total RNA was observed, allowing comparisons of fractions of specific RNAs between two growth conditions. Experiments have been repeated three times.

\section{Construction}

of the gene disruption vector and fungal transformation.

Homologous primers WOD (5'CGCGAAGCTTGTCTCCAGGACCTCTGCA3') and AFBR (5'CGCGAAGCTTTCTCCATGGACGTCCCAA3') containing HindIII sites were designed on the Bcpme1 cDNA sequence and were used to amplify an 831-bp product on genomic DNA by PCR (3 min at $94^{\circ} \mathrm{C}, 30$ cycles of $1 \mathrm{~min}$ at $94^{\circ} \mathrm{C}, 1 \mathrm{~min}$ at $62^{\circ} \mathrm{C}$, and $1 \mathrm{~min}$ at $72^{\circ} \mathrm{C}$, followed by $7 \mathrm{~min}$ at $72^{\circ} \mathrm{C}$ ). This product was cloned into the HindIII site of pAN7-1, leading to the plasmid pibcpmel used for transformation. Strain Bd90 was transformed with undigested pibcpmel according to Hamada and associates (1994). Transformants were single spores isolated on hygromycin-containing medium $(100 \mu \mathrm{g}$ per $\mathrm{ml})$. In order to make a first screening, two primers, AVWOD (5'CTTCTAGGAGCAGTCTCTG3') and FTtrpC (5'CACTCCACATCTCCACTCGA3'), were designed so that only DNA of homologous interrupted transformants could be amplified as $1-\mathrm{kb}$ product. Those transformants were further analyzed by Southern blotting.

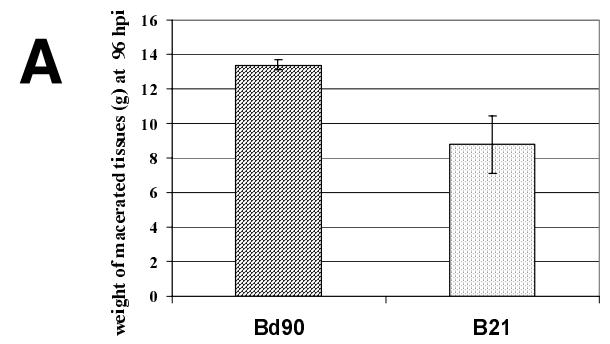

B
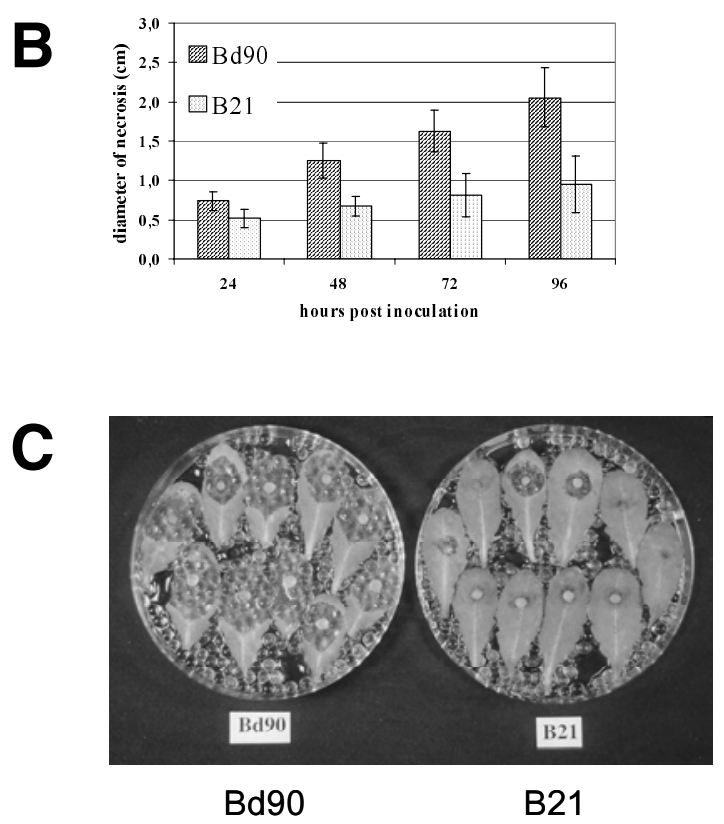

Fig. 6. Pathogenicity assays with the wild-type Bd90 and mutant B21 strains. A, On Granny Smith apple fruits. Fresh weight of macerated tissues at $96 \mathrm{~h}$ postinoculation (hpi). B, On Vitis vinifera Chardonnay leaves. Evolution of necrosis diameter. C, On Arabidopsis thaliana ecotype Ws leaves. Symptoms caused by strains Bd90 and B21 at 96 hpi. Bars indicate standard deviation of mean of three experiments. 
Table 1. Pathogenicity assay on Arabidopsis thaliana ecotype Ws leaves

\begin{tabular}{lcc}
\hline Strain $^{\text {a }}$ & $\begin{array}{c}\text { Necrosis diameter mean } \\
(\mathbf{c m}) \text { at } 96 \text { hpi }\end{array}$ & $\begin{array}{c}\text { Successful infection } \\
(\mathbf{\%}) \text { at } \mathbf{9 6} \text { hpi }\end{array}$ \\
\hline Bd90 & $1.89 \pm 0.31$ & 100 \\
B21 & $0.44 \pm 0.21$ & 33 \\
B21C & $1.60 \pm 0.16$ & 100 \\
\hline
\end{tabular}

${ }^{a}$ Bd90 (parental wild-type strain), B21 (Bcpme1 disrupted mutant), and B21C (complemented Bcpme1 transformant of B21).

${ }^{\mathrm{b}}$ Percentage of successful infections corresponds to the number of inoculations leading to infections divided by the number of total inoculations. An inoculation leading to an infection was considered successful when the lesion was more than $4 \mathrm{~mm}$ in diameter.

\section{Complementation of mutant B21.}

With primers bcpme1prCgata (5'GGAAAGCGTGATATTGTTGAT3'), located in the promoter of the Bcpmel gene, and bcpme1trC (5'GGGGTTCCAAGATGGGATGTTAG3'), located at the end of the known portion of the Bcpmel terminator, a product of 2,610 bp was amplified (Expand High Fidelity System; Roche Diagnostics, Meylan, France) on genomic DNA of wild-type strain Bd90. This PCR product was cloned in pGEM-T (Promega, Charbonnières, France), was digested by $A p a \mathrm{I}$ and SstI, and was introduced in vector pCB1265 (provided by M. H. Lebrun, Bayer Lyon), which contained a bar gene conferring resistance to the herbicide Basta, leading to plasmid pbcpme1C to transform mutant B21. For selection to Basta resistance, protoplast suspension was resuspended in MS1 medium $\left(\mathrm{NaNO}_{3}, 23.5 \mathrm{mM}\right.$; glucose, $111 \mathrm{mM}$; sucrose, $584 \mathrm{mM} ; 1 \%$ mineral solution $\left[\mathrm{KH}_{2} \mathrm{PO}_{4}, 735 \mathrm{mM} ; \mathrm{MgSO}_{4} ; 7\right.$ $\left.\mathrm{H}_{2} \mathrm{O}, 0.2 \mathrm{M} ; \mathrm{KCl}, 0.67 \mathrm{M} ; \mathrm{FeSO}_{4} ; 7 \mathrm{H}_{2} \mathrm{O}, 3.6 \mathrm{mM}, \mathrm{pH} 3.5\right]$ and agar $0.7 \%$ ) supplemented with $100 \mu \mathrm{g}$ of Basta per ml (Ammonium Glufosinate, Ehrenstorfer-Schäfers Gmbh Laboratory) and was spread over a petri dish with MS1 medium containing Basta. Transformants resistant to Basta appeared after 4 to 5 days.

\section{Quantitative measurement of PME activity.}

PME activity was measured by a colorimetric method with the $\mathrm{pH}$ indicator bromocresol green, according to Reignault and associates (1994). One unit of PME was the amount of enzyme that released $1 \mu$ mole of $\mathrm{H}^{+}$ions per min at $\mathrm{pH} 5.5$ and $25^{\circ} \mathrm{C}$.

\section{IEF-PAGE analysis.}

Fungus was cultivated in Czapeck synthetic medium supplemented with either $3 \%$ glucose, $1 \%$ PGA, or $1 \%$ pectin during three days at $21 \pm 1^{\circ} \mathrm{C}$. The culture media filtrated on miracloth were concentrated against 20 M PEG carbovax and then dialyzed in $50 \mathrm{mM}$ citrate phosphate buffer, $\mathrm{pH}$ 6.4. IEF-PAGE was performed as described by Bertheau and associates (1984). Preparation of extracts from healthy and infected apple fruits was performed as described by Reignault and associates (2000).

\section{Inoculation of plants and pathogenicity assays.}

Apple fruits (Malus domestica cv. Granny Smith) were acquired commercially and wound-inoculated with a 5-mm-diameter plug of mycelium from the edge of 3-day-old culture on solid NY. Strain Bd90 and mutant B21 were inoculated on the same apple fruit, and five apple fruits were used in each of the three experiments. For grapevine (Vitis vinifera cv. Chardonnay) and Arabidopsis thaliana ecotype Ws, detached leaves were inoculated without wounding on the adaxial face (plug of 3- or 5-mm diameter for A. thaliana and grapevine leaves, respectively). The leaves were put in petri dishes containing water and small beads to maintain a high humidity level. The petri dishes were incubated at $21 \pm 1^{\circ} \mathrm{C}$ and under daylight. After
Table 2. Pathogenicity assay on Vitis vinifera leaves

\begin{tabular}{lc}
\hline Strain $^{\mathbf{a}}$ & Necrosis diameter mean (cm) at 96 hpi \\
\hline Bd90 & $2.30 \pm 0.40$ \\
B21 & $1.25 \pm 0.32$ \\
B21C & $2.28 \pm 0.31$ \\
\hline
\end{tabular}

${ }^{a}$ Bd90 (parental wild-type strain), B21 (Bcpme1 disrupted mutant), and B21C (complemented Bcpme1 transformant of B21).

$24,48,72$, and $96 \mathrm{~h}$ postinoculation, the necrosis diameters were noted. The experiments were repeated three times with five leaves for grapevine tests and ten leaves for A. thaliana tests. Wild-type strain Bd90 was applied on the left side and mutant B21 on the right side of grapevine leaves. Strain Bd90 and mutant B21 were applied on different $A$. thaliana leaves, as they were too small to put the two strains on the same leaf. For Arabidopsis thaliana pathogenicity tests, we calculated a percentage of successful infections, which corresponded to the number of inoculations leading to infections divided by the number of total inoculations. An inoculation leading to infection was considered successful when the lesion was more than $4 \mathrm{~mm}$ in diameter (including plug diameter). The data shown in Table 1 and in Figures 5, 6A, and 6B are accumulated data from three experiments.

\section{ACKNOWLEDGMENTS}

We thank M. Choquer and A. Vidal-Cros for helpful discussions about RT-PCR and gene walking, R. Vedel for advice about IEF-PAGE techniques, C. Périno and D. Reis for their help concerning microscopical studies. O. Valette-Collet has been supported by a grant of Ministère National de l'Education, de la Recherche et de la Technologie. Investigations were supported by INRA and Université Pierre et Marie Curie, Paris.

\section{LITERATURE CITED}

Alghisi, P., and Favaron, F. 1995. Pectin-degrading enzymes and plantparasite interactions. Eur. J. Plant Pathol. 101:365-375.

The Arabidopsis Genome Initiative. 2000. Analysis of the genome of the flowering plant Arabidopsis thaliana. Nature. 408:796-815.

Bertheau, Y., Madgidi-Hervan, E., Koutoujanski, A., Nguyen-The, C. Andro, T., and Coleno, A. 1984. Detection of depolymerase isoenzymes after electrophoresis or electrofocusing, or in titration curves. Anal. Biochem. 139:383-389.

Beaulieu, C., Boccara, M., and Van Gijsegem, F. 1993. Pathogenic behavior of pectinase-defective Erwinia chrysanthemi mutants on different plants. Mol. Plant-Microbe Interact. 6:197-202.

Boccara, M., and Châtain, V. 1989. Regulation and role in pathogenicity of Erwinia chrysanthemi 3937 pectin methylesterase. J. Bacteriol. 17:4085-4087.

Bowen, K. J., Templeton, D. M. Sharrock, R. K., Crowburst, N. R., and Rikkerink, A. H. E. 1995. Gene inactivation in the plant pathogen Glomerella cingulata: Three strategies for disruption of the pectin lyase gene pnlA. Mol. Gen. Genet. 246:196-205.

Büttner, P., Koch, F., Quidde, T., Risch, S., Blaich, R., Bruckner, B., and Tudzynski, P. 1994. Variation of ploidy levels within Botrytis cinerea isolates: Implication for genetic and molecular analysis. Curr. Genet. 25:445-450.

Chilosi, G., and Milagro, P. 1997. Pectin lyase and polygalacturonase isoenzyme production by Botrytis cinerea during the early stages of infection on different host plants. J. Plant Pathol. 78:61-69.

Christgau, S., Kofod, L. V., Halkier, T., Andersen, L. N., Hockauf, M., Dörreich, K., Dalboge, H., and Kauppinen, S. 1996. Pectin methyl esterase from Aspergillus aculeatus: Expression cloning in yeast and characterization of the recombinant enzyme. Biochem. J. 319:705-712.

Coley-Smith, J. R., Verhoeff, K., and Jarvis, W. R. 1980. The biology of Botrytis. Academic Press, New York.

Faretra, F., Antonacci, E., Pollastro, S. 1988. Sexual behavior and mating system of Botryotinia fuckeliana, teleomorph of Botrytis cinerea. J. Gen. Microbiol. 134 :2543-2550.

Frittang, A. K., Deising, H., and Mendgen, K. 1992. Characterization and partial purification of pectinesterase, a differentiation-specific enzyme of Uromyces viciae-fabae. J. Gen. Microbiol. 138:2213-2218. 
Fu, Y. H., and Mazluf, G. A. 1990. nit-2, the major nitrogen regulatory gene in Neurospora crassa encodes a protein with a putative zinc finger DNA-binding domain. Mol. Cell. Biol. 10:1056-1065.

Gao, S., Choi, G. H., Shain, L., and Nuss, D. L. 1996. Cloning and targeted disruption of enpg-1, encoding the major in vitro extracellular endopolygalacturonase of the chestnut blight fungus, Cryphonectria parasitica. Appl. Environ. Microbiol. 62:1984-1990.

Hamada, W., Reignault, P., Bompeix, G., and Boccara, M. 1994 Transformation of Botrytis cinerea with hygromycine B resistance gene, $h p h$. Curr. Genet. 26:251-255.

Isshiki, A., Akimitsu, K., Yamamoto, M., and Yamamoto, H. 2001. Endopolygalacturonase is essential for citrus black rot caused by Alternaria citri but not brown spot caused by Alternaria alternata. Mol. Plant-Microbe Interact. 14:749-757.

Jenkins, J., Mayans, O., Smith, D., Worboys, K., and Pickersgill, R. W. 2001. Three-dimensional structure of Erwinia chrysanthemi pectin methylesterase reveals a novel esterase active site. J. Mol. Biol. 305:951-960.

Johansson, K., El-Ahmad, M., Friemann, R., Jörnvall, H., Markovic, O., Eklund, H. 2002. Crystal structure of plant pectin methylesterase. FEBS (Fed. Eur. Biochem. Soc.) Lett. 514:243-249.

Kapat, A., Zimand, G., and Elad, Y. 1998. Biosynthesis of pathogenic hydrolytic enzymes by Botrytis cinerea during infection of bean leaves and in vitro. Mycol. Res. 102:1017-1024.

Khanh, N. Q., Ruttkowski, E., Leidinger, K., Albrecht, H., and Gottschalk, M. 1991. Characterization and expression of a genomic pectin methyl esterase-encoding gene in Aspergillus niger. Gene. 106:71-77.

Kitamoto, N., Okada, H., Yoshino, S., Ohmiya, K., and Tsukagoshi, N. 1999. Pectin methylesterase gene (pmeA) from Aspergillus oryzae KBN616: Its sequence analysis and over-expression, and characterization of the gene product. Biosci. Biotechnol. Biochem. 63:120-124

Knox, J. P., Linstead, P. J., King J., Cooper, C., and Roberts, K. 1990 Pectin esterification is spatially regulated both within cell walls and between developing tissues of root apices. Planta. 181:512-521.

Kudla, B., Caddick, M. X., Langdon, T., Martinez-Rossi, N. M., Benett, C. F., Sibley, R., Davis, R. W., and Arst, H. N. 1990. The regulatory gene areA mediating nitrogen metabolite repression in Aspergillus nidulans. Mutations affecting specificity of gene activation alter a loop residue of a putative zinc finger. EMBO (Eur. Mol. Biol. Organ.) J. 9:1355-1364

Kulmburg, P., Mathieu, M., Dowzer, C., Kelly, J., and Felenbok, B. 1993. Specific binding sites in the alcR and alcA promoters of the ethanol regulon of the CREA repressor mediating carbon catabolite repression in Aspergillus nidulans. Mol. Microbiol. 7:847-857.

Laurent, F., Kotoujansky, A., Labesse, G., and Bertheau, Y. 1993. Characterization and overexpression of the pem gene encoding pectin methyl esterase of Erwinia chrysanthemi strain 3937. Gene. 131:1725.

Markovic, O., and Jörnal, H. 1992. Disulfide bridges in tomato pectinesterase: Variations from pectinesterases of other species; conservation of possible active site segments. Prot. Sci. 1:1288-1292.

Oeser, B., Heidrich, P. M., Müller, U., Tudzynski, P., Tenberge, K. B. 2002. Polygalacturonase is a pathogenicity factor in the Claviceps purpurea/rye interaction. Fungal Gen. Biol. 36:176-186.

Reignault, P., Mercier, M., Bompeix, G., and Boccara, M. 1994. Pectin methylesterase from Botrytis cinerea : Physiological, biochemical and immunochemical studies. Microbiol. 140:3249-3255.

Reignault, P., Kuntz, C., Delage, N., Moreau, E., Vedel, R., Hamada, W. Bompeix, G., Boccara, M. 2000. Host and symptom-specific pectinase isozymes produced by wild-type strains and pathogenicity-altered transformants of Botrytis cinerea. Mycol. Res. 104:421-428.

Rexova-Benkova, L., and Markovic, O. 1976. Pectic enzymes. Advances in carbohydrates chemistry and biochemistry. 33:323-385.

Rogers, L. M., Kim, Y. K., Guo, W., Gonzalès-Candelas, L., Li, D., and Kolattukudy, P. E. 2000. Requirement for either a host- or pectininduced pectate lyase for infection of Pisum sativum by Nectria hematococca. Proc. Natl. Acad. Sci. U.S.A. 97:9813-9818.

Sambrook, J., Fritsch, E. F., and Maniatis, T. 1989. Molecular Cloning : A Laboratory Manual. 2nd ed. Cold Spring Harbor Laboratory Press, Cold Spring Harbor, NY, U.S.A.

Scott-Craig, J. S., Cheng, Y., Cervone, F., De Lorenzo, G., Pitkin, J. W. and Walton, J. D. 1998. Targeted mutants of Cochliobolus carbonum lacking two major extracellular polygalacturonases. Appl. Environ. Microbiol. 64:1497-1503.

Shieh, M., Brown, R. L., Whitehead, M. P., Cary, J. W., Cotty, P. J., Cleveland, T. E., and Dean, R. A. 1997. Molecular genetic evidence for the involvement of a specific polygalacturonase, P2c, in the invasion of Aspergillus flavus in cotton bolls. Appl. Environ. Microbiol. 63:3548-3552.

Spök, A., Stubenrauch, G., Schorgendorfer, K., and Schwab, H. 1991. Molecular cloning and sequencing of pectinesterase gene from Pseudomonas solanacearum. J. Gen. Microbiol. 137:131-140.

Ten Have, A., Mulder, W., Visser, J., and van Kan, J. A. L. 1998. The endopolygalacturonase gene Bcpg1 is required for full virulence of Botrytis cinerea. Mol. Plant Microbe Interact. 11:1009-1016.

Ten Have, A., Tenberge, K. B., Benen, J. A. E., Tudzynski, P., Visser, J. and van Kan, J. A. L. 2002. The contribution of cell wall degrading enzymes to pathogenesis of fungal plant pathogens. Pages 341-358 in The Mycota XI, Agricultural Applications. F. Kempken, ed. SpringerVerlag, Berlin.

Tilburn, J., Sarkar, S., Widdick, D. A., Espeso, E. A., Orejas, M Mungeso, J., Penalva, M. A., and Arst, I.-H. A. 1995. The Aspergillus PacC zinc finger transcription factor mediates regulation of both acidic and alkaline expressed genes by ambient pH. EMBO (Eur. Mol. Biol. Organ.) J. 14:779-790.

Van den Ackerveken, G. F. J. M., Vossen, P., and De Wit, P. J. M. 1992. The AVR9 race-specific elicitor of Cladosporium fulvum is processed by endogenous and plant proteases. Plant Physiol. 103:91-96.

Voragen, A. G. J., Schols, H. A., Pilnik, W. 1986. Determination of the degree of methylation and acetylation of pectins by HPLC. Food Hydrocoll. 1:65-70.

Wubben, J. P., Mulder, W., Ten Have, A., Van, J. A. L, and Visser, J. 1999. Cloning and partial characterization of endopolygalacturonase genes from Botrytis cinerea. Appl. Environ. Microbiol. 65:1596-1602.

Yakoby, N., Freeman, S., Dinoor, A., Keen, N. T., and Prusky, D. 2000. Expression of pectate lyase from Colletotrichum gloeosporioides in C. magna promotes pathogenicity. Mol. Plant-Microbe Interact. 13:887-891.

\section{AUTHOR-RECOMMENDED INTERNET RESOURCE}

The Génoscope-Centre de séquençage website: www.genoscope.cns.fr 